\title{
Uji Akurasi Metode Berbasis Citra Satelit untuk Ekstraksi Data Batimetri
}

\author{
Ayu Nur Safi'i, Ratna Sari Dewi \\ Badan Informasi Geospasial \\ Jl. Raya Jakarta-Bogor Km. 46 Cibinong, Kabupaten Bogor, Indonesia 16911
}

\begin{abstract}
Abstrak
Citra penginderaan jauh memungkinkan pengumpulan data batimetri dengan cakupan luas, sehingga dapat diintegrasikan dengan informasi terestrial untuk pemodelan wilayah pesisir dan pemodelan garis pantai. Data batimetri berbasis citra satelit cukup menjanjikan karena kemampuannya untuk mengisi kesenjangan data kedalaman yang diperoleh dari survei hidrografi. Tujuan dari penelitian ini difokuskan untuk mengevaluasi tiga model dalam memperoleh informasi kedalaman. Model-model tersebut dibuat dengan mengintegrasikan data citra penginderaan jauh dan data pengukuran in-situ (pemeruman) untuk menyediakan dan mengisi data kedalaman di perairan dangkal kawasan pesisir antara permukaan laut dan batas awal data pemeruman. Tiga model yang dievaluasi yaitu: Random Forest (RF), Multi Linear Regression (MLR) dan Generalized Additive Model (GAM). Secara statistik (hasil RMSE), GAM lebih unggul dibandingkan MLR dan RF dalam memperoleh informasi kedalaman. Nilai RMSE masing-masing adalah 0,16, 0,32 dan 0,64 untuk GAM, MLR dan RF. Namun, dari hasil visualisasi, model SDB dengan menggunakan GAM sangat 'smooth'. Sementara jika dilihat dari penggunaan data, RF sangat tergantung pada jumlah data training. Dalam hal ini, MLR cukup menjanjikan untuk digunakan dalam memperoleh informasi kedalaman karena memiliki akurasi model SDB yang baik dan memiliki pola kedalaman yang lebih andal/reliable. Selain itu, MLR tidak terlalu tergantung pada jumlah data training.
\end{abstract}

Kata kunci: kedalaman; batimetri; batimetri berbasis citra; perairan dangkal, penginderaan jauh, SBES

\begin{abstract}
[Title: Evaluating the Accuracy of Satellite Derived Bathymetry] Remote sensing images enable the collection of wide coverage bathymetry data to be integrated by terrestrial information to develop coastal terrain models and shoreline models. Satellite-derived bathymetry is promising due to its ability to fill the gap of depth from hydrographic survey. The objective of this research is focused on the assessment of three models in deriving depth information. The models were created by integrating remote sensing images and in-situ measurement data to provide and fill the near-shore gap between sea level and the beginning of sounding data. Three models have been assessed, namely: Random Forest (RF), Multi Linear Regression (MLR), and Generalized Additive Model (GAM). From the RMSE results, we found that GAM outperformed MLR and RF in deriving depth information. The RMSE values were 0.16, 0.32, and 0.64 for $G A M, M L R$, and RF, respectively. However, from the visualization results, we can see that the SDB model using GAM was smooth excessively. Meanwhile, based on the train data used, RF was very dependent on the number of training data. In this case, MLR was promising to be used for deriving depth information. It has a good accuracy of SDB model, and it has a more reliable depth pattern. Moreover, MLR was not very much dependent on the number of training data.
\end{abstract}

Keywords: depth; bathymetry; satellite derived bathymetry; shallow water, remote sensing, SBES

\footnotetext{
${ }^{*}$ Penulis Korespondensi.

E-mail: ayunursafii.10@gmail.com
}

\section{Pendahuluan}

Pengukuran kedalaman laut khususnya pada perairan dangkal sebagian besar dilakukan dengan menggunakan survei batimetri, diantaranya pengukuran menggunakan echosounder (Dierssen \& Theberge, 2016). 


\section{TEKNIK, 41 (2), 2020, 143}

Akan tetapi pengukuran dengan metode ini memiliki kelemahan. Kapal yang membawa echosounder tidak dapat mengakses perairan dangkal karena alasan keamanan (Pattanaik dkk., 2015) terutama perairan yang di bawahnya banyak ditemukan terumbu karang. Selain menggunakan echosounder, dijelaskan juga oleh Vinayaraj (2017) bahwa pengukuran perairan dangkal dapat menggunakan SoNAR dan airbone LiDAR. Hasil pengukuran batimetri dari kedua metode ini sangat akurat, sebagaimana dinyatakan oleh penelitian terdahulu bahwa akurasi pengukuran batimetri menggunakan LiDAR mencapai sekitar $2 \mathrm{~cm}$ (Abdallah dkk., 2013; Yeu dkk., 2018), namun memiliki kelemahan dari sisi biaya dan ketersediaan teknologi yang terbatas (Vinayaraj dkk., 2016).

Seiring dengan perkembangan zaman, mulai dikembangkan model kedalaman laut yang didapatkan melalui citra satelit atau lebih dikenal dengan istilah Sattellite Derrived Bathymetry (SDB). Metode ini dapat digunakan sebagai alternatif yang efisien, efektif, cepat dan murah untuk mengukur kedalaman perairan (Arya dkk. 2016; Vinayaraj, 2017). Ada berbagai sumber citra satelit yang dapat dimanfaatkan untuk penentuan kedalaman perairan, mulai dari citra satelit resolusi tinggi seperti WorldView (Chénier dkk., 2018) dan QuickBird (Mishra dkk., 2006) hingga resolusi menengah seperti Landsat (Misra dkk., 2018).

Ekstraksi data kedalaman menggunakan citra penginderaan jauh optik dihitung berdasarkan prinsip bahwa jumlah total energi elektromagnetik yang dipantulkan dari kolom air adalah fungsi dari kedalaman air (Casal dkk., 2019). Penginderaan jauh optik memanfaatkan radiasi gelombang pendek pada spektrum biru dan hijau yang memiliki kemampuan penetrasi yang kuat ke dalam air. Ketika radiasi matahari merambat melalui air, radiasi itu tersebar dan diserap oleh molekul air dan konstituen dalam air, meninggalkan beragam energi untuk dihamburkan dan direkam dalam citra penginderaan jauh. Kemudian dinyatakan bahwa energi yang diterima oleh sensor berbanding terbalik dengan kedalaman air setelah dilakukan koreksi atmosfer dan koreksi kolom air. Oleh karena itu, intensitas sinyal yang dikembalikan ke sensor menunjukkan kedalaman dimana radiasi matahari telah menembus (Jawak \& Luis, 2015). Pemodelan batimetri dapat dikelompokkan atas pemodelan analitik, semianalitik dan pemodelan empiris dari transmisi cahaya matahari melalui atmosfer dan kolom air (Mavraeidopoulos dkk., 2017; Vinayaraj, 2017). Intensitas cahaya yang masuk ke dalam tubuh air senantiasa akan mengalami penurunan dengan bertambahnya kedalaman laut (Geyman \& Maloof, 2019). Nilai spektral objek perairan yang terekam oleh sensor satelit dipengaruhi oleh dasar, permukaan dan kedalaman perairan itu sendiri (Kanno \& Tanaka, 2012). Sedangkan berdasarkan kandungan material, maka perairan terbagi menjadi perairan keruh dan jernih. Perairan pantai Kecamatan Cilebar adalah salah satu pantai dengan kandungan material keruh (Yuwono \& Sidad, 2017). Pantulan nilai spektral untuk perairan keruh lebih tinggi dibandingkan dengan perairan yang lebih jernih (Nurkhayati, 2013).

Beberapa metode telah dikembangkan untuk menentukan kedalaman laut yang diawali penelitian Lyzenga (1978a). Selanjutnya berkembang penelitian terkait ekstraksi kedalaman sejalan dengan ketersediaan citra penginderaan jauh yang semakin luas diantaranya yang dapat diacu adalah Philpot (1989), Kanno $d k k$., (2013), Stumpf dkk., (2003) dan Chénier dkk., (2018).

Penelitian ini bertujuan untuk mengetahui kemampuan citra satelit multi-kanal SPOT 6 untuk memetakan kedalaman laut. Tiga algoritma yaitu regresi linear berganda (multi linear regression/MLR), random forest (RF) dan generalized additive model (GAM) diuji dan dibandingkan untuk mengekstraksi data kedalaman di perairan dangkal, sehingga dapat diketahui bagaimana akurasi yang didapatkan dari masing-masing metode beserta kelebihan dan kekurangannya. Selain itu, penelitian terdahulu kebanyakan mengujikan algoritma SDB untuk perairan jernih. Sedangkan dalam penelitian ini, kehandalan dan konsistensi metode-metode tersebut diuji di perairan yang keruh. Sehingga akan diperoleh informasi apakah metode yang sama memiliki kehandalan yang sama pada jenis perairan berbeda dengan turbiditas yang lebih tinggi. Diharapkan informasi ini dapat berguna bagi pembaca, terutama para pengambil keputusan yang bertanggung jawab dalam penyediaan data batimetri.

\section{Metode Penelitian}

\subsection{Lokasi penelitian}

Lokasi Penelitian dilakukan di wilayah Pantai Kecamatan Cilebar, Jawa Barat (lihat Gambar 1), pada koordinat 6 9' 5,3" $-6^{\circ} 6^{\prime}$ ' 11,909' LS dan $107^{\circ} 27^{\prime} 18,13$ "' - $107^{\circ} 29^{\prime} 13,11^{\prime \prime}$ BT. Pantai ini adalah pantai dengan aktivitas pelabuhan yang tidak terlalu ramai. Tipe pasang surut di lokasi ini adalah tipe pasang surut harian ganda dengan magnitudo formahzl 1,202 (Yuwono \& Sidad, 2017).

\subsection{Data yang digunakan dan proses awal yang dilakukan}

Dalam penelitian ini, data yang digunakan meliputi data citra penginderaan jauh dan data pemeruman SBES (Single Beam Echo Sounding). Citra penginderaan jauh yang digunakan adalah SPOT 6 perekaman tanggal 24 Mei 2017. Selanjutnya dilakukan koreksi atmosfer menggunakan metode Dark Pixel Subtraction (DOS) yaitu mengambil sejumlah piksel pada masing-masing kanal di laut dalam, kemudian nilai tersebut dirata-rata dan digunakan sebagai faktor pengurang nilai piksel masing-masing kanal (Green dkk., 2000). 


\section{TEKNIK, 41 (2), 2020, 144}

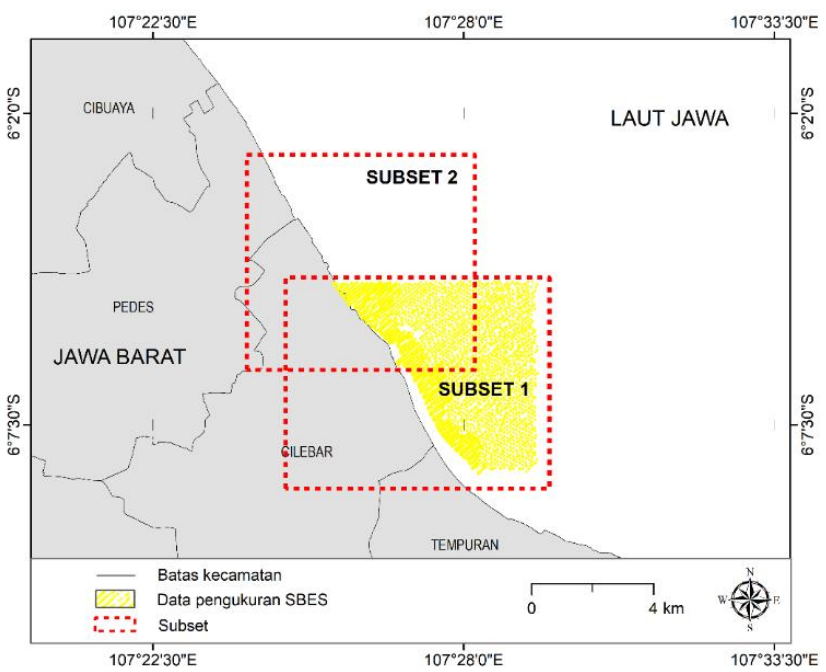

Gambar 1. Lokasi Penelitian di pantai Kecamatan Cilebar; kumpulan titik kuning merupakan lokasi pengukuran SBES; dan kotak garis putus-putus berwarna merah adalah lokasi subset ketika melakukan eksperimen.

Persamaan yang digunakan adalah Persamaan 1.

$$
L_{\mathrm{i}}^{n}=L_{\mathrm{i}}-L_{s i}
$$

dimana $L_{i}^{s}$ adalah nilai piksel terkoreksi pada kanal $i ; L_{i}$ adalah nilai piksel awal pada kanal $i$; dan $L_{g i}$ adalah nilai piksel rata-rata sampling di laut dalam pada kanal $i$. Metode ini mengasumsikan pada area laut dalam energi gelombang elektromagnetik diserap habis sehingga nilai dari reflektansi yang ada dapat diasumsikan sebagai nilai reflektansi dari suatu atmosfer (Arya dkk., 2016).

Dalam melaksanakan eksperimen, dua subset citra penginderaan jauh digunakan sebagaimana terlihat pada Gambar 1 (ditandai kotak garis putus-putus berwarna merah). Tujuan dibentuknya dua subset ini adalah untuk menguji konsistensi hasil model SDB. Selanjutnya digunakan dua kombinasi kanal citra SPOT 6, yaitu kanal 231 (red-green-blue) dan kanal 2314 (redgreen-blue-NIR) yang memiliki resolusi spasial $6 \mathrm{~m}$. Hal ini untuk mengetahui bagaimana pengaruh komposisi kanal terhadap model SDB yang dihasilkan. Secara umum ketersediaan kanal pada citra SPOT 6 dapat dilihat pada Tabel 1 (Astrium Services, 2013).

Data kedua yang digunakan adalah data SBES hasil pemeruman tahun 2015 dimana data ini digunakan untuk membangun dan memvalidasi model. Data pemeruman sudah dikoreksi terhadap kondisi pasang surut. Selanjutnya dalam eksperimen ini data pemeruman tersebut dibagi menjadi data training dan testing dengan variasi proporsi $75: 25 \%, 50: 50 \%$ dan $25: 75 \%$. Hal ini bertujuan untuk melihat pengaruh data training/sampel untuk menghasilkan model kedalaman.

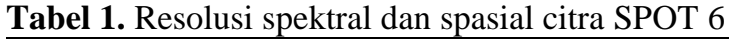

\begin{tabular}{llll}
\hline Kanal & Karakter & $\begin{array}{c}\text { Panjang } \\
\text { Gelombang }(\boldsymbol{\mu m})\end{array}$ & $\begin{array}{c}\text { Resolusi } \\
(\mathbf{m})\end{array}$ \\
\hline Kanal 1 & Blue & $0,455-0,525$ & 60 \\
Kanal 2 & Red & $0,530-0,590$ & 10 \\
Kanal 3 & Green & $0,625-0,695$ & 10 \\
Kanal 4 & Near Infrared & $0,760-0,890$ & 10 \\
\hline
\end{tabular}

\subsection{Estimasi kedalaman}

Deskripsi metode yang digunakan dalam penelitian ini:

a. Random forest $(R F)$

$\mathrm{RF}$ membangun model regresi yang menghubungkan citra satelit dengan data kedalaman air. Breiman (2001) menjelaskan bahwa metode RF diimplementasikan dengan membuat pohon menggunakan: 1) data training misalnya data kedalaman; dan 2) nilai spektral dari citra satelit sebagai variabel prediktor. Nilai RF sangat bergantung pada nilai acak vektor dan memiliki distribusi yang sama untuk semua pohon (tree) yang berada di hutan (forest). Hasil analisis tergantung pada korelasi antar pohon. Untuk lebih detil terkait RF, pembaca disarankan untuk merujuk Breiman (2001). Sementara itu, aplikasi RF untuk ekstraksi data kedalaman dapat dilihat pada hasil penelitian Manessa dkk., (2016) dan Sagawa (2019). Untuk eksperimen dalam penelitian ini, ada dua parameter RF yang diujicobakan yaitu parameter ntree yang melambangkan jumlah pohon yang akan diestimasi pada pengolahan RF; dan parameter mtry yang melambangkan jumlah variable yang diambil secara acak sebagai kandidat pada setiap pemisahan. Adapun nilai ntree yang diuji mulai dari 100 - 1000 pada kelipatan 100, sedangkan nilai mtry yang diuji adalah 1,3 dan 5 .

\section{b. Multi Linier Regression (MLR)}

Kemampuan MLR dalam memprediksi nilai kedalaman menggunakan citra satelit dapat dilihat di beberapa penelitian yang telah dilakukan (Clark dkk., 1987; Dwi dkk., 2017; Hamilton dkk., 1993; Kanno \& Tanaka, 2012; M. Manessa dkk., 2016; Ratna Sari Dewi dkk., 2019; Setiawan dkk., 2018). Penggunaan MLR diawali dari penelitian Clark dkk., (1987) yang menganalisis citra satelit menggunakan metode regresi berganda antara suatu kedalaman in-situ dan citra multispektral yang digunakan untuk mengestimasi koefisien regresi. Selanjutnya, koefisien-koefisien ini digunakan untuk memperkirakan nilai kedalaman. Metode ini membahas heterogenitas dari tipe dasar dengan memanfaatkan semua kanal sinar tampak. Metode ini menggunakan kedalaman dari data pemeruman (echosounder) yang digunakan sebagai variable terikat, sedangkan log transformasi kanal dari masing-masing citra digunakan sebagai variabel bebasnya. Hengel dan Spitzer (1991) menyatakan bahwa metode MLR ini 


\section{TEKNIK, 41 (2), 2020, 145}

bekerja dengan asumsi bahwa nilai reflektansi dasar perairan dan komposisi air bernilai tetap diseluruh bagian citra penginderaan jauh, dan nilai kanal multispektral dipengaruhi oleh reflektansi dasar perairan. Adapun persamaan yang digunakan untuk memperkirakan nilai kedalaman dapat dilihat pada Persamaan 2 (Van Hengel \& Spitzer, 1991; Vinayaraj, 2017),

$$
w_{d}=\beta_{0}+\beta_{1} X_{1}+\beta_{2} X_{2}+\cdots+\beta_{n} X_{\mathrm{i}}
$$

dimana $\beta_{0}$ adalah $y$-intercept, $\beta_{1}, \beta_{2}, \ldots, \beta_{n}$ adalah nilai gradien dari masing-masing kanal dan $X_{1}, X_{2}, \ldots, X_{\mathrm{i}}$ adalah nilai radiansi yang ditransformasi untuk masing-masing kanal. Nilai koefisien $\beta$ diperoleh ketika mengimplementasikan MLR menggunakan data training dari SBES.

\section{c. Generalized Additive Model (GAM)}

GAM dikembangkan dengan menggunakan multiple smoothing dari beberapa parameter seperti marginal likelihood, dan generalized cross validation (Wood, 2019). Kelebihan GAM adalah memiliki fitur untuk menggeneralisasi seluruh model dengan membiarkan fungsionalitas non-linear dari semua variable. GAM memiliki dasar pemodelan dengan menggunakan fungsi "smoothers". Beberapa pemodelan smoothing yang digunakan adalah regression splines, local regression dan smoothing splines (Ravindra dkk.,, 2019). Untuk ekstraksi data kedalaman, kombinasi metode Lyzenga (1978b) dengan metode interpolasi spasial yang dibangun oleh Kanno dkk., (2011b) dilakukan untuk memodelkan "term error" pada metode Lyzenga berdasarkan ketergantungan spasial yang disebut regresi semi-parametrik, sesuai Persamaan 3 (Kanno $d k k .,, 2011 \mathrm{a}, 2011 \mathrm{~b})$ :

$$
h=\mathrm{X} \beta+t(z)+\varepsilon^{\prime}
$$

dimana $X$ dan $\beta$ berasal dari pengukuran SBES dan citra penginderaan jauh pada kanal sinar tampak. Sementara $t(z)$ adalah fungsi non-parametrik "smoother" koordinat dua dimensi vektor $z$ dan $\varepsilon^{t}$ adalah nilai tengah variabel acak. Dalam penelitian ini, GAM dijalankan menggunakan perangkat lunak $\mathrm{R}$ dengan paket 'mgcv'. Selanjutnya GCV (Generalized Cross Validation) digunakan untuk mengoptimasi fungsi 's' dan regresi 'splines' dengan derajat kebebasan tertentu. Langkah yang cukup penting dalam mengimplementasikan SDB model adalah dalam menentukan derajat kebebasan ' $k$ ' ini, dimana nilai $k$ tidak boleh terlalu besar atau terlalu kecil. Dalam eksperimen, nilai $k$ yang digunakan bervariasi mulai dari $10-100$ dalam kelipatan 10 .

\subsection{Uji Akurasi Model SDB}

Uji akurasi model SDB dilakukan dengan menggunakan data testing SBES seperti yang dinyatakan pada sub-bab 2.2. Secara umum, uji akurasi dilakukan dengan membandingkan data kedalaman yang dihasilkan model SDB dan data kedalaman hasil pemeruman. Akurasi model SDB yang menggunakan tiga algoritma RF, MLR dan GAM, dihitung dengan model statistik Root Mean Square Error (RMSE). RMSE ini adalah suatu ukuran akurasi yang sangat umum digunakan untuk membandingkan kesalahan prediksi dari dua variable continue yang menunjukkan fenomena yang sama, misalnya perbandingan antara suatu teknik pengukuran dengan teknik pengukuran yang lain (Ismunarti $d k k$., 2020; Neill \& Hashemi, 2018). Teknik pengukuran kedalaman dalam penelitian ini adalah membandingkan hasil prediksi SDB (data testing) dengan pengamatan echosounder (data training). RMSE dihitung menggunakan persamaan 4 .

$$
\operatorname{RMSE}_{\text {(depth) }}=\Sigma \sqrt{\frac{\left(Y_{i}-Y_{i}^{f}\right)^{2}}{N}}
$$

dimana $Y_{\hat{f}}$ adalah nilai kedalaman atual dari data testing, $Y_{i}^{t}$ adalah nilai kedalaman dari model SDB dan $\mathrm{N}$ adalah jumlah data kedalaman. Metode yang mendekati kondisi riil dari data hasil ekstrasi kedalaman laut dapat dilihat dari nilai RMSE yang dihasilkan dari masing-masing metode.

\section{Hasil Model SDB}

Proses estimasi kedalaman laut menggunakan tiga model SDB yaitu RF, MLR dan GAM memberikan hasil yang berbeda-beda sebagaimana dijelaskan berikut ini.

\subsection{Model SDB random forest}

Hasil ekstraksi kedalaman menggunakan RF sebagaimana terlihat pada Gambar 2, menunjukkan bahwa proporsi training $75 \%$ menggunakan kombinasi empat kanal (RGBN) memberikan nilai RMSE lebih baik. Gambar 2 juga menunjukkan bahwa subset 1 memiliki akurasi yang lebih baik dibandingkan subset 2 karena cakupan data training yang lebih banyak. Selanjutnya hasil eksperimen juga menunjukkan bahwa variasi ntree tidak berpengaruh signifikan terhadap hasil model SDB. Meskipun demikian, terlihat bahwa meningkatkan nilai ntree menjadi lebih tinggi (bahkan sampai nilai 1000) hanya menurunkan nilai RMSE sebanyak 0,01 .

Pengaturan nilai mtree memberikan sedikit pengaruh pada nilai RMSE, hasil terbaik umumnya diperoleh jika mtry $=5$ (Gambar 3). Secara umum, RMSE terbaik yang dihasilkan oleh metode RF adalah 0,64 ketika ntree $=1000$, mtry $=1$ pada subset 1 menggunakan empat kanal. 


\section{TEKNIK, 41 (2), 2020, 146}

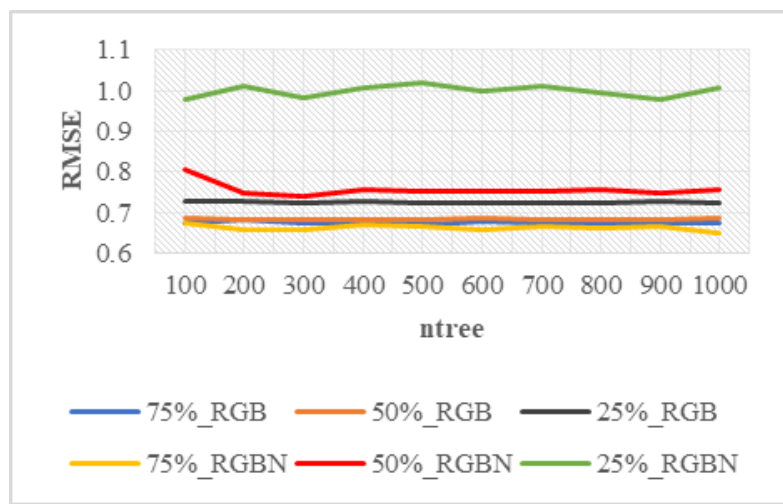

Gambar 2. Perbandingan nilai RMSE model SDB menggunakan algoritma RF untuk kombinasi 3 dan 4 kanal (RGB dan RGBN) dimana nilai mtry $=1$ pada subset $1(\mathrm{R}=$ red; $\mathrm{G}=$ green; $\mathrm{B}=$ blue dan $\mathrm{N}=\mathrm{NIR})$.

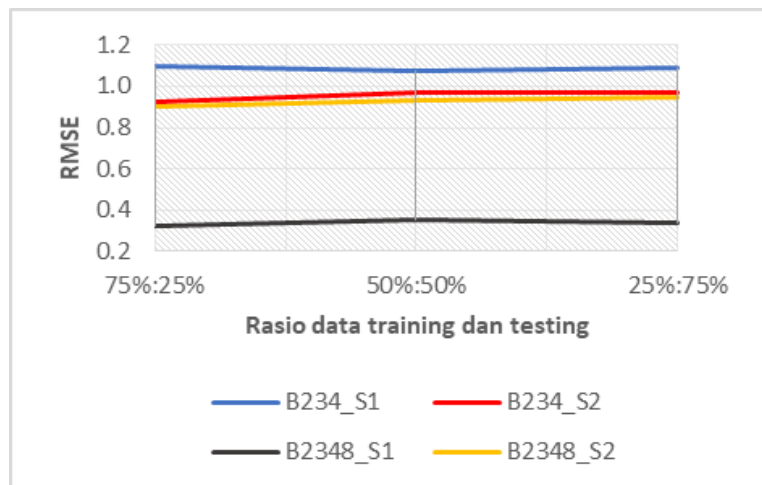

Gambar 4. Perbandingan nilai RMSE model SDB menggunakan algoritma MLR untuk kombinasi tiga dan empat kanal (RGB dan RGBN) pada subset 1 (untuk keterangan notasi RGBN dapat dilihat pada judul Gambar 2)

\subsection{Model SDB multi linear regression}

Hasil ekstraksi kedalaman menggunakan MLR ditampilkan pada Gambar 4. Dari gambar tersebut terlihat bahwa penambahan kanal NIR meningkatkan akurasi secara signifikan. Hal ini terlihat dari nilai RMSE subset 1 yang menjadi semakin kecil yaitu dari 1,096 menjadi 0,324. Selain itu, dapat dilihat juga bahwa dengan adanya penambahan maupun pengurangan data training tidak berpengaruh besar terhadap hasil yang didapat. Hasil RMSE terbaik dari metode MLR adalah 0,324 pada subset 1 menggunakan empat kanal RGBN.

\subsection{Model SDB generalized additive model}

Gambar 5 menunjukkan perbandingan model SDB menggunakan GAM pada kombinasi kanal RGB dan RGBN. Terlihat bahwa kombinasi empat kanal memberikan akurasi sedikit lebih baik dibanding kombinasi tiga kanal. Dari Gambar 5 juga terlihat

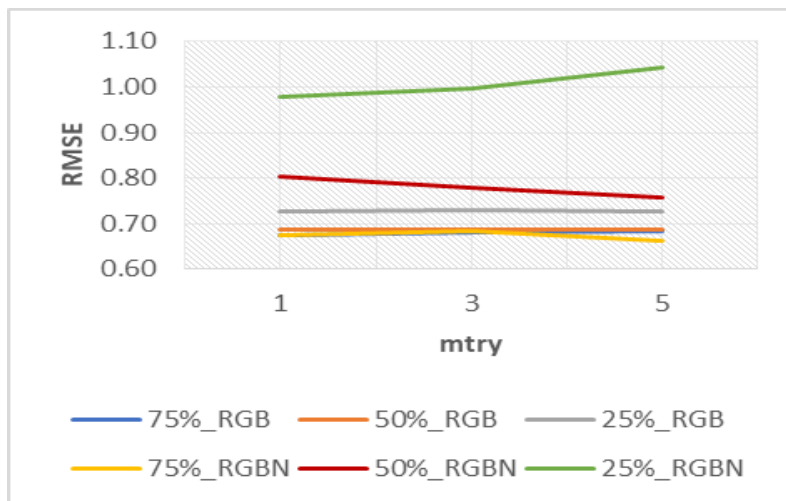

Gambar 3. Perbandingan nilai RMSE model SDB menggunakan algoritma RF untuk kombinasi 3 dan 4 kanal (RGB dan RGBN) pada subset 1, dimana nilai ntree $=100$ (keterangan notasi di Gambar 2).

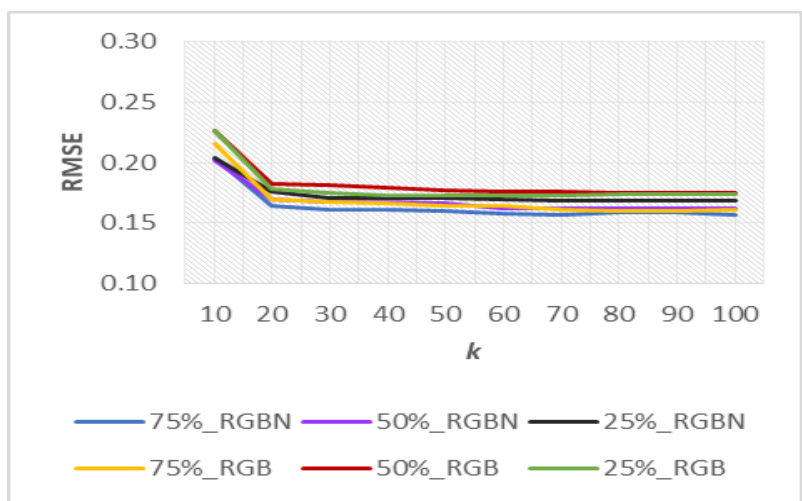

Gambar 5. Perbandingan nilai RMSE model SDB menggunakan algoritma GAM untuk kombinasi 3 dan 4 kanal (RGB dan RGBN) pada subset 2 (keterangan notasi di Gambar 2).

bahwa peningkatan nilai $k$ berpengaruh cukup besar ketika nilai $k$ diubah dari 10 menjadi 20, sedangkan selanjutnya peningkatan nilai $k$ hanya memberikan peningkatan nilai RMSE yang sangat kecil.

Selanjutnya, dari hasil eksperimen juga diketahui bahwa variasi jumlah training data memberikan pengaruh yang sangat kecil terhadap perbaikan nilai RMSE. Nilai RMSE terbaik dari metode GAM adalah 0.156 pada subset 2 dengan nilai $k=100$ dan jumlah data training adalah $75 \%$ dari seluruh data pemeruman.

\subsection{Perbandingan Model SDB}

Hasil eksperimen menggunakan metode RF memberikan nilai kedalaman sampai 9,2 m, metode MLR memberikan kedalaman 19,7 m, sementara GAM kedalaman yang dapat dideteksi sampai 10,5 m. Terlihat bahwa MLR mampu mendeteksi perairan yang cukup dalam. Selanjutnya Gambar 6 


\section{TEKNIK, 41 (2), 2020, 147}

menunjukkan perbandingan tiga model SDB dalam penelitian ini menggunakan kombinasi kanal RGB dan RGBN. Terlihat bahwa nilai RMSE yang diperoleh algoritma RF sangat dipengaruhi oleh variasi proporsi jumlah data training dan testing. Sementara hasil model GAM dan MLR, kurang dipengaruhi oleh variasi proporsi data training dan testing (kecil dari 0,01\%).

Apabila kita melihat hasil eksperimen ketika menggunakan jumlah kanal yang berbeda (Gambar 6), maka terlihat bahwa penggunaan citra dengan empat kanal (RGBN) memberikan hasil paling baik dibandingkan ketika menggunakan citra dengan tiga kanal (RGB). Hal ini dapat dilihat pada model SDB ketika menggunakan RF dan MLR, sementara ketika menggunakan GAM, penggunaan citra dengan tiga kanal memberikan hasil yang sedikit lebih baik, namun perbedaannya sangat kecil.

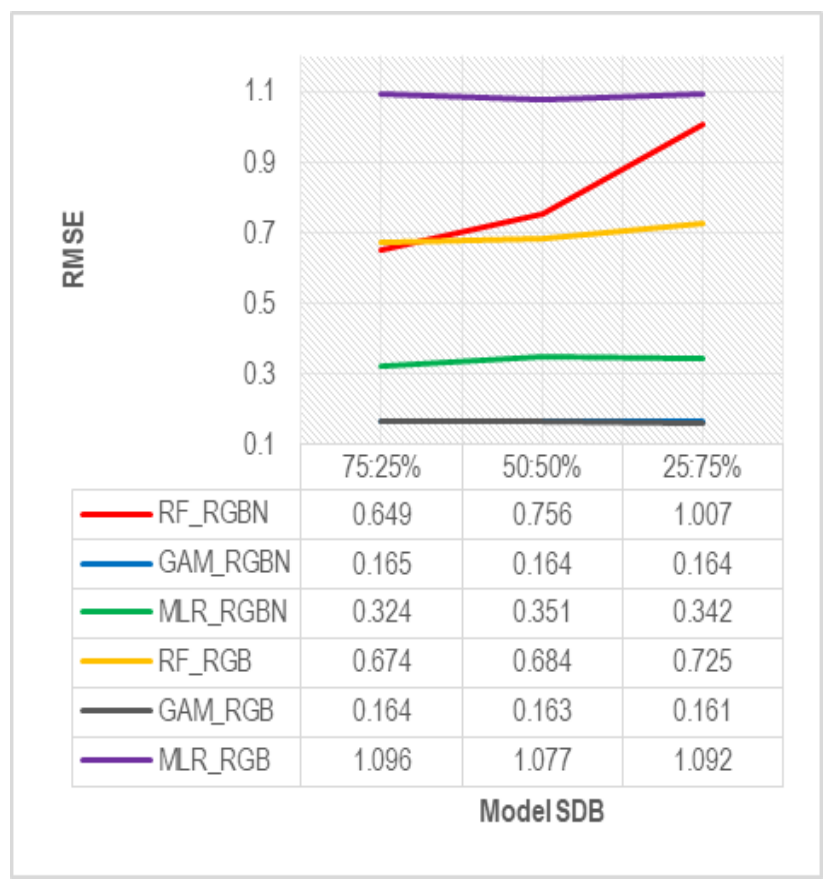

Gambar 6. Perbandingan nilai RMSE model SDB menggunakan algoritma RF, GAM dan MLR dengan kombinasi tiga dan empat kanal (RGB dan RGBN) pada subset 1 (keterangan notasi di Gambar 2).

Dari ketiga model, terlihat bahwa GAM memberikan nilai RMSE paling kecil yang mengindikasikan paling akurat. Sementara MLR yang menggunakan empat kanal juga memberikan nilai RMSE yang cukup baik dibanding dengan RF. Akan tetapi, jika dilihat hasil model SDB secara visual pada Gambar 7, model SDB menggunakan GAM memiliki visualisasi yang kurang alami, terlihat seperti oversmoothing (lihat Gambar 7c). Sementara model SDB menggunakan MLR terlihat memiliki pola kedalaman yang paling mendekati kondisi di alam. Hal ini dapat dicek secara visual menggunakan citra natural komposit di Gambar 7d pada sel B2 dan C3. Piksel yang berwarna hitam di Gambar 7b memiliki rentang kedalaman $0-1 \mathrm{~m}$ yang merupakan area perairan yang mengandung endapan sedimen (lumpur/pasir) ditandai warna putih/abu terang pada Gambar 7d.

Gambar 8 memperlihatkan perbandingan profil melintang data pemeruman dengan data kedalaman hasil model SDB. Dari profil melintang ini terlihat bahwa kurva SBES dan GAM mengalami overfitting. Kurva MLR dan RF di Plot1 terlihat bersesuaian dengan kurva SBES di perairan yang lebih dalam dan sebaliknya di perairan dangkal. Sementara kurva MLR dan RF di Plot2 terlihat bersesuaian (fit) dengan kurva SBES di perairan dangkal, akan tetapi bergeser (shifting) di area yang lebih dalam.

\subsection{Pembahasan}

Dalam penelitian ini, secara umum, penambahan kanal NIR meningkatkan perfoma algoritma SDB untuk menghasilkan informasi kedalaman, kecuali untuk GAM dimana kombinasi tiga kanal memberikan nilai RMSE yang sedikit lebih baik. Meskipun demikian, perbedaan nilai RMSE yang dihasilkan kedua kombinasi kanal (RGB dan RGBN) sangat kecil sehingga dapat diabaikan. Dalam hal ini jumlah kanal yang digunakan dalam model pada dasarnya akan mempengaruhi kemampuan algoritma dalam membedakan tipe dasar dan massa air, sehingga penggunaan lebih banyak kanal mungkin akan menghasilkan model yang lebih akurat (Bramante dkk., 2013). Akan tetapi perlu diketahui bahwa berdasarkan Jupp (1988) dalam Green dkk., (2000), kanal infrared akan sepenuhnya diserap di dalam kolom air. Sementara kanal NIR dapat menembus perairan sampai kedalaman $0.5 \mathrm{~m}$. Hasil eksperimen berdasarkan nilai RMSE menunjukkan bahwa GAM memiliki performa yang terbaik dan dari profil melintang, kurva GAM sangat bersesuaian dengan kurva SBES. Hal ini mungkin disebabkan karena korelasi yang sangat tinggi antara data training dan testing yang digunakan dalam model SDB. Dalam studi ini, data training dan testing dipilih secara acak sehingga mungkin saja keduanya memiliki distribusi dan berasal dari lokasi yang sama. Terlebih lagi, secara visual dapat dilihat bahwa GAM memberikan model SDB yang oversmoothing. Oleh karena itu, untuk penelitian lanjutan, disarankan untuk memilih data training dan testing yang benar-benar terpisah. 


\section{TEKNIK, 41 (2), 2020, 148}

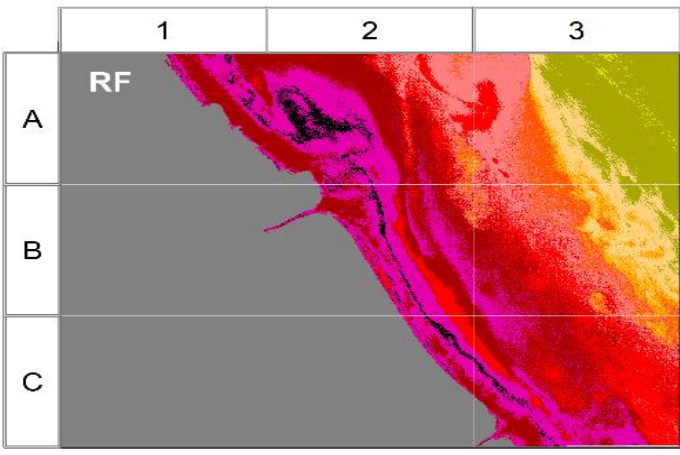

(a)

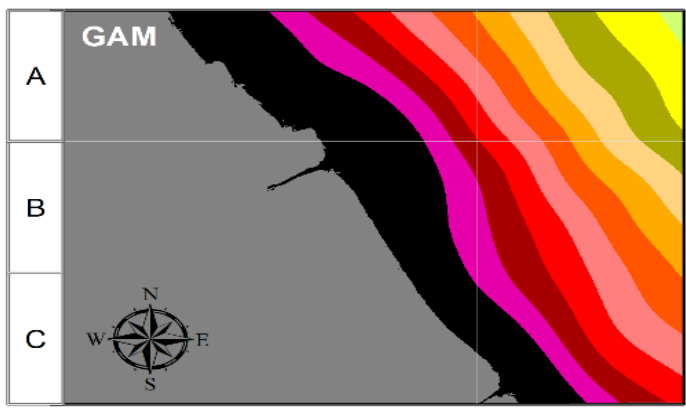

(c)

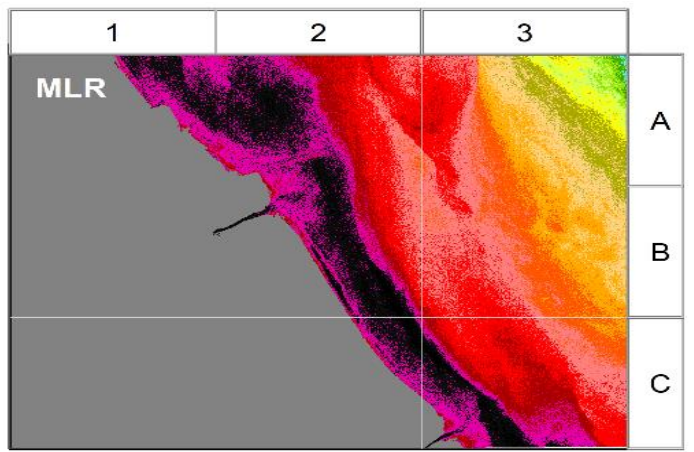

(b)

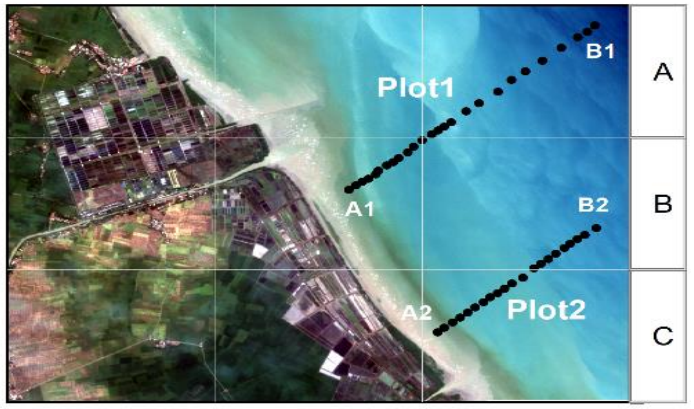

(d)

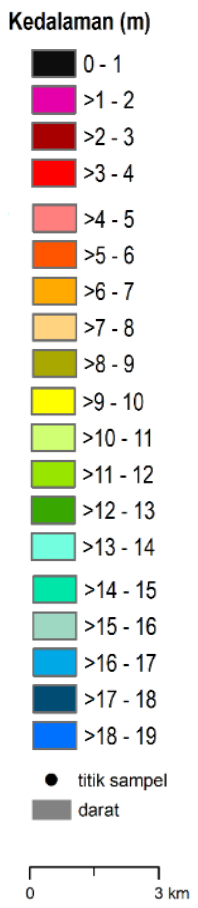

Gambar 7. Visualisasi model SDB menggunakan algoritma (a) RF (ntree $=1000, m$ try $=1$ ); (b) GAM $(k=100$ ); dan (c) MLR dengan kombinasi empat kanal (d) RGBN dengan natural komposit pada subset 1 dan titik-titik berwarna hitam menunjukkan titik sampel untuk profil melintang model kedalaman.

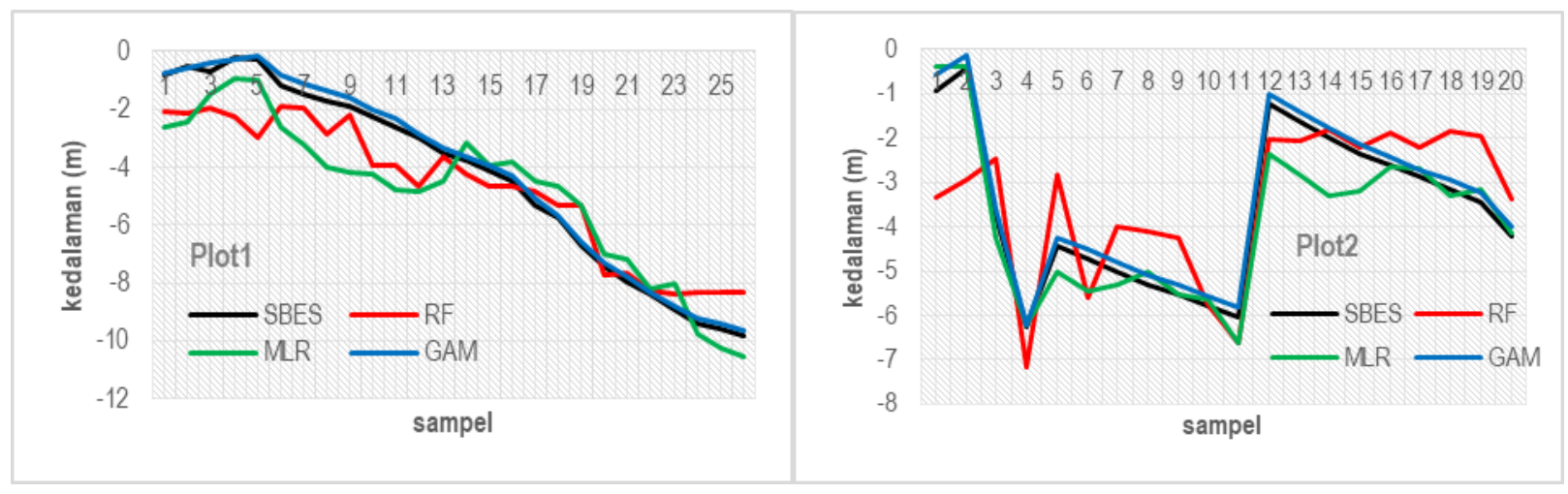

Gambar 8. Profil melintang menunjukkan perbandingan antara data hasil pemeruman (SBES) dengan model SDB untuk lokasi Plot 1 dan 2 pada Gambar 7d. Profil melintang dimulai dari A dan berakhir di B.

Dalam penelitian ini terlihat bahwa MLR lebih baik dari pada RF. Hal ini cukup mengejutkan mengingat dalam penelitian-penelitian lain yang dilakukan di perairan jernih, RF jauh lebih unggul dibandingkan dengan MLR (Dewi dkk., 2020; Dwi dkk., 2017). Hal ini mungkin disebabkan oleh kondisi perairan yang berbeda. Seperti dinyatakan oleh Cahalane dkk., (2019) bahwa secara umum model SDB sangat dipengaruhi oleh jenis sensor, kualitas air dan kondisi lingkungan lainnya. Dalam hal ini terlihat bahwa RF sangat dipengaruhi oleh kondisi perairan dibandingkan oleh MLR.

Selanjutnya dengan memberikan rasio training dan testing yang berbeda, terlihat bahwa MLR tidak 


\section{TEKNIK, 41 (2), 2020, 149}

terlalu dipengaruhi oleh jumlah data training yang digunakan. Dengan eror kurang dari 0,5 m, MLR cukup menjanjikan untuk digunakan di perairan yang keruh.

\section{Kesimpulan}

Penelitian ini menyajikan analisis komparatif dari tiga model SDB dengan membandingkan variasi proporsi data training dan testing serta komposit kanal citra SPOT 6. Model MLR dengan nilai RMSE sekitar 0,3 , meskipun tidak memberikan nilai RMSE terbaik akan tetapi secara visual memberikan hasil yang paling reliable. Sementara metode RF dengan nilai RMSE 0,61,0 juga memberikan hasil yang baik, akan tetapi sangat dipengaruhi oleh jumlah training data, mengindikasikan tidak cocok digunakan jika jumlah data training sedikit dan tidak cocok untuk perairan yang keruh. Penelitian lebih lanjut diperlukan untuk menjelaskan kesalahan model dan korelasi antara data training dan testing dalam model SDB.

Dalam penelitian ini, karena keterbatasan data yang tersedia hanya digunakan empat kanal dari citra SPOT 6. Penelitian untuk menguji kehandalan model SDB menggunakan kombinasi kanal yang lebih banyak dan menjadi rekomendasi untuk penelitian lanjutan di masa yang akan datang.

\section{Ucapan Terima Kasih}

Terima kasih disampaikan kepada Lembaga Penerbangan dan Antariksa Nasional yang telah menyediakan data SPOT 6 untuk penelitian ini; dan kepada Pusat Pemetaan Kelautan dan Lingkungan Pantai - Badan Informasi Geospasial yang telah menyediakan data pemeruman wilayah studi. Selanjutnya ucapan terima kasih disampaikan kepada Aldino Rizaldy dan Prayudha Hartanto yang telah mempersiapkan script code yang digunakan dalam penelitian ini dan juga untuk diskusi mengenai SDB selama penelitian ini dilakukan.

\section{Daftar Pustaka}

Abdallah, H., Bailly, J. S., Baghdadi, N. N., SaintGeours, N., \& Fabre, F. (2013). Potential of spaceborne LiDAR sensors for global bathymetry in coastal and inland waters. IEEE Journal of Selected Topics in Applied Earth Observations and Remote Sensing. https://doi.org/10.1109/JSTARS.2012.2209864

Arya, A., Winarso, G., \& Santoso, A. I. (2016). Evaluasi Akurasi Ekstrasi Kedalaman Laut dengan Metode Lyzenga dan Modifikasinya Menggunakan Data SPOT-7 di Teluk Belagbelang Mamuju. Jurnal Ilmiah Geomatika, 22(1), 9-19. https://doi.org/10.24895/JIG.2016.22-1.423
Astrium Services. (2013). SPOT 6 \& SPOT 7 imagery user guide. In Astrium Services.

Bramante, J. F., Raju, D. K., \& Sin, T. M. (2013). Multispectral derivation of bathymetry in Singapore's shallow, turbid waters. International Journal of Remote Sensing, 34(6), 2070-2088. https://doi.org/10.1080/01431161.2012.734934

Breiman, L. (2001). Random Forests. Machine Learning, 45(1), 5-32. https://doi.org/10.1023/A:1010933404324

Cahalane, C., Magee, A., Monteys, X., Casal, G., Hanafin, J., \& Harris, P. (2019). A comparison of Landsat 8, RapidEye and Pleiades products for improving empirical predictions of satellitederived bathymetry. Remote Sensing of Environment. https://doi.org/10.1016/j.rse.2019.111414

Casal, G., Monteys, X., Hedley, J., Harris, P., Cahalane, C., \& McCarthy, T. (2019). Assessment of empirical algorithms for bathymetry extraction using Sentinel-2 data. International Journal of Remote Sensing. https://doi.org/10.1080/01431161.2018.1533660

Chénier, R., Faucher, M.-A., \& Ahola, R. (2018). Satellite-Derived Bathymetry for Improving Canadian Hydrographic Service Charts. In ISPRS International Journal of Geo-Information (Vol. 7, Issue 8). https://doi.org/10.3390/ijgi7080306

Clark, R. K., Fay, T. H., \& Walker, C. L. (1987). Bathymetry calculations with Landsat 4 TM imagery under a generalized ratio assumption. Applied Optics, 26(19), 4036_1-4038. https://doi.org/10.1364/AO.26.4036_1

Dewi, R. S., Lumban-Gaol, Y., Safi'I, A. N., Rizaldy, A., Syetiawan, A., \& Rahadiati, A. (2020). Assessing the effect of various training and testing set ratios to model the satellite derived bathymetry. IOP Conference Series: Earth and Environmental Science. https://doi.org/10.1088/1755-1315/500/1/012032

Dierssen, H. M., \& Theberge, A. E. (2016). Bathymetry: Assessment. In Encyclopedia of Natural Resources: Water (pp. 629-636). Taylor \& Francis. https://doi.org/10.1081/e-enrw120048588

Dwi, M., Manessa, M., Haidar, M., Hastuti, M., Kresnawati, D. K., Division, T. M., \& Sensing, R. (2017). Determination Of The Best Methodology For Bathymetry Mapping Using Spot 6 Imagery: A Study Of 12 Empirical. International Journal of Remote Sensing and Earth Sciences, 14(2), 127136.

Geyman, E. C., \& Maloof, A. C. (2019). A Simple Method for Extracting Water Depth From Multispectral Satellite Imagery in Regions of 


\section{TEKNIK, 41 (2), 2020, 150}

Variable Bottom Type. Earth and Space Science. https://doi.org/10.1029/2018EA000539

Green, E., Mumby, P., Edwards, A., \& Clark, C. (2000). Remote Sensing Handbook for Tropical Coastal Management.

Hamilton, M. K., Davis, C. O., Rhea, W. J., Pilorz, S. H., \& Carder, K. L. (1993). Estimating chlorophyll content and bathymetry of Lake Tahoe using AVIRIS data. Remote Sensing of Environment, 44(2-3), 217-230.

Ismunarti, D. H., Zainuri, M., Sugianto, D. N., \& Saputra, S. W. (2020). Pengujian Reliabilitas Instrumen Terhadap Variabel Kontinu Untuk Pengukuran. Buletin Osenaografi Marina, 9(1), 18. https://doi.org/10.14710/buloma.v9i1.23924

Jawak, S. D., \& Luis, A. J. (2015). Spectral information analysis for the semiautomatic derivation of shallow lake bathymetry using high-resolution multispectral imagery: A case study of Antarctic coastal oasis. Aquatic Procedia, 4(Icwrcoe), 1331-1338.

https://doi.org/10.1016/j.aqpro.2015.02.173

Kanno, A., Koibuchi, Y., \& Isobe, M. (2011a). Statistical Combination of Spatial Interpolation and Multispectral Remote Sensing for Shallow Water Bathymetry. IEEE Geoscience and Remote Sensing Letters, 8(1), 64-67. https://doi.org/10.1109/LGRS.2010.2051658

Kanno, A., Koibuchi, Y., \& Isobe, M. (2011b). Shallow Water Bathymetry from Multispectral Satellite Images: Extensions of Lyzenga's Method for Improving Accuracy. Coastal Engineering Journal, 53(4), 431-450. https://doi.org/10.1142/S0578563411002410

Kanno, A., \& Tanaka, Y. (2012). Modified lyzenga's method for estimating generalized coefficients of satellite-based predictor of shallow water depth. IEEE Geoscience and Remote Sensing Letters, $9(4)$, $715-719$. https://doi.org/10.1109/LGRS.2011.2179517

Kanno, A., Tanaka, Y., Kurosawa, A., \& Sekine, M. (2013). Generalized Lyzenga's Predictor of Shallow Water Depth for Multispectral Satellite Imagery. Marine Geodesy, 36(4), 365-376. https://doi.org/10.1080/01490419.2013.839974

Lyzenga, D. R. (1978a). Passive remote sensing techniques for mapping water depth and bottom features. Applied Optics, 17(3), 379-383. https://doi.org/10.1364/AO.17.000379

Lyzenga, D. R. (1978b). Passive remote sensing techniques for mapping water depth and bottom features. Applied Optics, 17(3), 379. https://doi.org/10.1364/ao.17.000379

Manessa, M. D. M., Kanno, A., Sekine, M., Haidar, M., Yamamoto, K., Imai, T., \& Higuchi, T. (2016).
Satellite-Derived Bathymetry using Random Forest Algorithm and Worldview-2 Imagery. Geoplanning: Journal of Geomatics and Planning; Vol 3, No 2 (2016): (October 2016)DO

10.14710/Geoplanning.3.2.117-126. https://ejournal.undip.ac.id/index.php/geoplanning /article/view/12047

Manessa, M., Kanno, A., Sekine, M., Haidar, M., Yamamoto, K., Imai, T., \& Higuchi, T. (2016). Satellite Derived Bathymetry Using Random Forest Algorithm and Worldview-2 Imagery. Geoplanning, 3(2), 117-126. https://doi.org/10.14710/geoplanning.3.2.117-126

Mavraeidopoulos, A., Navy, H., Pallikaris, A., Academy, H. N., \& Oikonomou, E. (2017). Satellite Derived Bathymetry (SDB) and Safety of Navigation. May.

Mishra, D., Narumalani, S., Rundquist, D., \& Lawson, M. (2006). Benthic habitat mapping in tropical marine environments using quickbird multispectral data. Photogrammetric Engineering and Remote Sensing. https://doi.org/10.14358/PERS.72.9.1037

Misra, A., Vojinovic, Z., Ramakrishnan, B., Luijendijk, A., \& Ranasinghe, R. (2018). Shallow water bathymetry mapping using Support Vector Machine (SVM) technique and multispectral imagery. International Journal of Remote Sensing, 39(13), 4431-4450. https://doi.org/10.1080/01431161.2017.1421796

Neill, S. P., \& Hashemi, M. R. (2018). Ocean Modelling for Resource Characterization. In Fundamentals of Ocean Renewable Energy. https://doi.org/10.1016/b978-0-12-8104484.00008-2

Nurkhayati, R. (2013). Pemteaan Batimetri Perairan Dangkal Menggunakan Citra Quickbird di Perairan Taman Nasional Karimun Jawa, Kabupaten Jepara, Jawa Tengah. Jurnal Bumi Indonesia, 2(2), 140-148.

Pattanaik, A., Sahu, K., \& Bhutiyani, M. R. (2015). Estimation of Shallow Water Bathymetry Using IRS-Multispectral Imagery of Odisha Coast, India. Aquatic Procedia, 4, 173-181. https://doi.org/https://doi.org/10.1016/j.aqpro.201 5.02 .024

Philpot, W. D. (1989). Bathymetric mapping with passive multispectral imagery. Applied Optics, 28(8), https://doi.org/10.1364/AO.28.001569

Ratna Sari Dewi, Hartanto, P., Oktaviani, N., Pujawati, I., Nursugi, \& Aditya, S. (2019). Satellite-Derived Bathymetry to Improve Bathymetric Map of Indonesia. Proceeding of LISAT Conference 2019.

Ravindra, K., Rattan, P., Mor, S., \& Aggarwal, A. N. 


\section{TEKNIK, 41 (2), 2020, 151}

(2019). Generalized additive models: Building evidence of air pollution, climate change and human health. In Environment International. https://doi.org/10.1016/j.envint.2019.104987

Sagawa, T., Yamashita, Y., Okumura, T., \& Yamanokuchi, T. (2019). Satellite derived bathymetry using machine learning and multitemporal satellite images. Remote Sensing. https://doi.org/10.3390/rs11101155

Setiawan, K. T., Dwi, M., Manessa, M., Winarso, G., \& Anggraini, N. (2018). Estimasi Batimetri dari Data Spot 7 Studi Kasus Perairan Gili Matra Nusa Tenggara Barat. Jurnal Penginderaan Jauh Dan Pengelolaan Data Citra Digital, 15(2), 69-82.

Stumpf, R., Holderied, K., \& Sinclair, M. (2003). Determination of Water Depth with HighResolution Satellite Imagery over Variable Bottom Types. Limnol. Oceanogr, 48, 547-556. https://doi.org/10.4319/lo.2003.48.1_part_2.0547

Van Hengel, W., \& Spitzer, D. (1991). Multi-temporal water depth mapping by means of Landsat TM. International Journal of Remote Sensing, 12(4),
$703-712$.

Vinayaraj, P. (2017). Development of Algorithms for Near-shore Satellite Derived Bathymetry Using Multispectral Remote Sensing Images. 1.

Vinayaraj, P., Raghavan, V., \& Masumoto, S. (2016). Satellite-Derived Bathymetry using Adaptive Geographically Weighted Regression Model. Marine Geodesy, 39(6), 458-478. https://doi.org/10.1080/01490419.2016.1245227

Wood, S. (2019). Package ' mgcv .' https://doi.org/10.1201/9781315370279>

Yeu, Y., Yee, J. J., Yun, H. S., \& Kim, K. B. (2018). Evaluation of the accuracy of bathymetry on the nearshore coastlines of western korea from satellite altimetry, multi-beam, and airborne bathymetric LiDAR. Sensors (Switzerland). https://doi.org/10.3390/s18092926

Yuwono, \& Sidad, B. F. (2017). Studi Tentang Pembangunan Pelabuhan Cilamaya ditinjau dari Aspek Teknis (Studi Kasus : Pelabuhan Cilamaya Karawang). Geoid, 12(2), 173-180. 